\title{
Colonising the Future: Mega-Trade Deals, Education Services and Global Higher Education Markets
}

\author{
Susan L. Robertson
}

University of Cambridge

Forthcoming

Special issue for Futures:

"Beyond Instrumentalism: The Dynamic Co-Constitution of Education and the Future" Editors: Keri Facer \& Sarah Amsler 


\begin{abstract}
This paper explores a less well-examined aspect of time in relation to higher education and the academy; that of 'time-future'. The paper takes the case of education trade strategies being pursued by governments and allied agencies, and explores the multiple ways in which time-future is mobilised. Drawing on trade documents, government statistics, and related reports, the paper points to two time-future dynamics at work. The first dynamic focuses on the ways in which the future is imagined by strategic actors, and legitimating through creating equivalences between education trade, economic growth and prosperity. The second dynamic explores the ways in which the current round of global and regional trade negotiations colonise the future as a political resource. I reflect on how time-future is a key resource and modality of power to be claimed and cognitively shaped so as to reorient actor's expectations towards the rhythms and demands of capitalism, and away from the temporal orders of the academy. However, efforts to commodify higher education, on the one hand, and colonise higher education futures exclusively to serve the interests of economic investors, on the other, continue to be contested. As a result, a new temporal order is yet to become common-sense, and an existing order is yet to die.
\end{abstract}




\section{Introduction}

A special issue given over to exploring the relationship between education, time and the future is an opportunity to think in more theoretically informed ways about this relation. To be sure, time features implicitly in the work of social scientists concerned with the social and political nature of education; for example, when they explore questions of social mobility, social reproduction, shifts in education governance over time, and so on. Education policy analysts also implicitly invoke time and the future in their examination of policies, most of which are aimed at bringing about some kind of change into the future. This state of affairs is not just an issue for social theorists of education. Helga Nowotny, in a seminal essay on time and social theory published in 1992, argues that whilst time has more recently featured as a context and theme of research into social life, theorising social time in a more substantive way has continued to lag behind. This is in part because, as Barbara Adam reminds us "...time is a deeply taken-for-granted aspect of social life" (1990: 9).

Over the past two decades, there has been a growing engagement with time by social theorists, including the nature of social time in education sectors and settings. In Timewatch, Adam (1995) has a whole chapter on a range of education practices. She shows the ways in which, through the hidden curriculum, "...dominant temporal structures and norms of society are absorbed, maintained, re-created and changed in daily educational practice" (p. 59). Through clocks, timetables and schedules, children in western schools learn how long, in what order, and with what speed to work both now and into the future. Researchers of educational processes also use complex time orders, from time series data to trends and panel reports that in turn orient us socially and cognitively to the world in particular ways.

Much of the more recent work on social time in higher education explores the way in which time is mediated by neo-liberal globalisation: for example, academic thought time is recast as money time (cf. Noonan, 2016); academic work is experienced by individuals as one of time shortages (cf. Ylijoki and Mäntylä 2003; Vostal, 2015, 2016); research time is experienced as a juxtaposition of different temporalities (Lapping, 2016). Yet aside from work on scenarios and other forms of horizon scanning (cf. Vincent-Lancrin, 2004; Blass et al., 2010), the substantive theorising of time-future in higher education remains relatively under-developed, and particularly so in relation to questions of power, and of the future as a resource to be colonised.

My entry point in this paper will be the analysis of a case of the discursive recasting of higher education as a global trade in services sector. Drawing on trade documents and related reports, I point to two time-future dynamics. Firstly, I will focus on the diverse ways in which the future is imagined by strategic actors, and legitimating through creating equivalences between education trade and economic growth and prosperity. Secondly, I will show the way in which the current round of global and regional trade negotiations, such as the Trade in Services Agreement (TISA), the Trans-Pacific Partnership (TPP), Comprehensive Economic Trade Agreement (CETA) and the Transatlantic Trade and Investment Partnership (TTIP), all seek to colonise the future as a resource (Hägerstrand, 1985) through mechanisms 
such as progressive liberalisation/lock-in clauses so as to place these agreement off limits to democratic politics into the future.

Briefly, progressive liberalisation refers to the further extension and deepening of 'freemarket' policies aimed at limiting state regulations. Lock-in clauses are used to place limits on governments putting a brake on, or reversing, liberalisation tendencies via increased state regulation. Future-time is thus a critical political resource to be captured, whilst individual actor's orientations to this different market future needs to also be recalibrated so as to stabilise new meanings, practices and commonsense. These mega-trade agreements seek to transform the future into an extended present (Nowotny, 1994), whilst the extended present contains the progressive cognitive reorientation of actors to a future shaped by capitalist dynamics (Beckert, 2016). However, efforts to commodify higher education and colonise higher education futures exclusively to serve the interests of economic investors continue to be contested. As a result, a new temporal order is yet to become common-sense, and an existing order is yet to die. The structure of the paper is as follows. I begin with an account of efforts to reimagine higher education and its temporal order and how this in turn challenges the orientations of contemporary academics and institutionalised social practices. I then turn to a brief outline of the work of Jens Beckert (2016) and Helga Nowotny $(1992,1994,2016)$ as resources to analyse the case of global higher education markets and trade and how their realisation within capitalist markets involves the cognitive reorientation of actors.

\section{Higher Education for a Globalising World}

There has recently been an explosion of education and futures work by governments and international organisations, including the Organisation for Economic Cooperation and Development (OECD), aimed at challenging and changing the ways in which teaching and learning in higher education is organised and delivered (see OECD, 2000; Vincent-Lancrin, 2004). Such 'futuring' activities include the development of scenarios about current and future states of education, the promotion of foresight and horizon scanning activities aimed at managing both the risks that might impede the realisation of future states (Robertson and Muellerleile, 2016) and the risks of ignoring radical changes already taking place in the higher sector that could lead to catastrophic outcomes (Barber et al., 2014).

What these strategic interventions represent are explicit efforts to reshape higher education through imagining different kinds of challenges and futures for its institutions and subjects. Such efforts suggest not only distinct (and thus potentially competing) imaginaries and temporalities at work, but they in turn demand, and produce, particular kinds of cognitive orientations to time - as in time-past, time-present, and time-future. The classic metaphor of the Ivory Tower to describe the social-world of the university, with its enclosed spaces, quiet libraries and cloistered walkways, invokes the idea of time-space separate from the boisterous tempo of the outside world. In this world, academics are simultaneously tasked with the mantle of being guardians of accumulated past knowledge, whilst oriented to the present and the future by the diligent search for truth. In this socio-temporal order, blue 
skies research takes time, experiments can and do fail, and new knowledge is the happy outcome of serendipity. Uncertainties about the future are not as much uncertainties about bad investments or collapsing share prices (though as higher education becomes more and more wired into the global circuit of capital this is an inevitable outcome), but about what forms new knowledge might take, or even more prosaically, what my first-year class will be like this year! (Back, 2016)

Whilst clearly a caricature of the temporal order of higher education, and not all academics experience current changes as all bad, what the literature on time in the academy does agree on is that the pace of life and control over time in the academy has changed. Vostal $(2015,2016)$ shows not only that the structure of academic life and its temporal rhythms are being recalibrated but that these shifts can be linked to changes in the relationship between higher education and global capital. A shift away from one temporal order to another takes ideational, institutional and regulatory work, and the question of how we can understand this theoretically in relation to the social and political nature of time is the purpose of the following section.

\section{The Temporal Orders of Capitalism and Its Orientations}

Any argument around higher education, the future, and the inclusion of education more directly in capital accumulation, suggests we need to look more closely at capitalism as a dynamic, and at its distinct temporal order. Here the work of Nowotny (1992, 1994, 2016) and Beckert (1996, 2014, 2016) are particularly useful for my purposes. In her recent book The Cunning of Uncertainty, Nowotny writes:

The arrow of time continues to advance the tenuous balance between the punctuated, incomplete and biased knowledge of the past and the uncertainty of what the future might bring. ...Ever since the modern societies manifested an unprecedented preference for generating novelty, the future became an open horizon with science and technology at the forefront, pushing further into the unknown (2016: vi).

Uncertainty is a powerful incentive in striving for more knowledge, and an inherent component of research within the academy (Nowotny, 2016: vi-xiii). And whilst capitalism itself is always seeking to manage the uncertainties surrounding the future, it is paradoxically also stimulated by innovation and feeds off of uncertainty, for instance through financial practices, such as hedge funds, risk assessments and insurance policies.

Jens Beckert has developed an impressive corpus of work on the temporal order of capitalism (cf. Beckert, 1996, 2014, 2016) that is particularly useful in that in developing a sociology of capitalism, he is particularly attentive to the temporal nature of social orders. Like others, Beckert (2014: 2-3) argues that both modernity and capitalism embrace distinctly different temporal orders in contrast to pre-modern and pre-capitalist orders.

Whilst pre-modern societies see themselves as living in a fixed, eternal present, by way of contrast modern societies tend to view the future as open and uncertain, or as a storehouse 
of possibilities. Yet as he also notes, much of the writing on temporalities and temporal orientations by sociologists has tended to focus on the development of modern societies and the political, rather than the economic. In speaking to this absence, he poses the question: "...how do perceptions of an open and uncertain future relate to the capitalist economy"? (Beckert, 2014: 3)

To answer his question, Beckert (2014: 3) turns to the work of the French sociologist, Pierre Bourdieu, and his accounts of the Kabyle people in French-controlled Algeria. Bourdieu was particularly interested in changes in temporal order within Kabylian society as a result of capitalist modernization in Algeria. He notes how the social and temporal logics of traditional Kabylian society, of solidarity and honour, were eventually replaced by attitudes toward calculation and future profits. This led to "...conflicts in Kabylian society triggered by different forms of economic thinking and new practices which were ultimately destroying the traditional social order" (op. cit: 4). The main point to be derived from looking at the breakdown of a traditional society like this, Beckert argues, is to "...highlight the shift in temporal orientation as being at the heart of capitalism's unfolding dynamic" (ibid). Beckert explores how economic decision-making amongst actors takes place in capitalist orders, and particularly so under conditions of uncertainty about the future:

...capitalism institutionalizes an organization of economic activity in which actors orient themselves toward an open and unforeseeable future. Such a future represents both unlimited possibilities for actors as well as a permanent threat to their economic status. At the macro level, the actions induced by this temporal order produce growth as well as sporadic crises, and thus the relentless dynamics of capitalism (2014: 1 ).

In an emerging capitalist order, actors ranging from companies to entrepreneurs, investors, employees and consumers must all orient their activities to a more open and uncertain future. "The temporary disposition of economic actors toward the future, and the capability to fill this future with counterfactual economic imaginaries, is crucial to understanding both how capitalism diverges from the economic orders that preceded it, and its overall dynamic" (Beckert, 2016: 2).

The paradox for both modernity and capitalism is that, ontologically, the future is open, uncertain, and by definition cannot be known. How, then, do actors orient themselves and make decisions? Beckert (2016) argues that actors have perceptions of the social world, and that they develop expectations about the future that in turn influence their decisions. But these decisions cannot be rational. Rather they are combinations of (i) what is thought to be currently the case (tomorrow will be like today), (ii) emotions, such as pride or status around imagined future states, and (iii) the expectations of others. Yet given that the future is unknown, they are in essence 'fictional expectations'. They are 'fictional' in that they provide an orientation in decision-making "...despite the incalculability of the outcomes" (Beckert, 2014: 9). They are 'expectations' in that they are social and not individual phenomena, and are shaped by collective beliefs formed from communicative practices ranging from laypeople to firms, politicians, experts and the media, and are crucial in the formation of imagined futures. 
Fictional expectations refer to the images actors form as they consider future states of the world, the ways in which they visualise causal relations, and the ways in which they also perceive their actions as influencing outcomes. The term also refers to the symbolic qualities actors ascribe to goods that transcend the good's material features. These orient their decision-making despite the fact that the future in modern capitalist societies cannot be known. "Actors, motivated by an imaginary future state, organize their activities based on this mental representation and the emotions associated with it" (Beckert, 2016: 9). As a result, "in economic practice, fictional expectations take a narrative form, and become articulated as stories that tell how the future will look and how the economy will unfold into the future from the current state of affairs" (Beckert, 2016: 10). These stories are embedded in frames, which include an ensemble of economic theories, such as development, risk and calculation, or technological progress, and are mediated through the deployment of a range of technologies and instruments, such as maps, schedules, statistical trends, impact assessments, risk analyses, and so on.

There are four main 'social' implications of Beckert's $(2014 ; 2016)$ fictional expectations thesis. First, fictional expectations help actors work together in concert in the face of uncertainty. In the context of higher education, this may be universities aligning with governments to ensure that institutional risks are minimised, or universities within a region collaborating to minimise risk. Second, there are real-world consequences in that these expectations help to affect the future (that is they are performative), but they are also broader, in that economic theories are not the only framings of a situation with the potential to lead to outcomes, and they do not necessarily lead to the anticipated future. Third, the contingency of expectations is a source of innovation in the economy, giving rise to new ideas despite, and because of, uncertainty. And fourth, the contingency of expectations gives rise to a politics of expectations.

In the following section I illustrate how such a politics of expectations underpins the discursive, material and institutional work involved in imagining, socialising and normalising trade in higher education whilst faced with struggles over the meaning and purposes of education and its forms of governance. As we will see, actors' different expectations and their associated imaginaries around education - as variously a public good, human right or tradeable service - have become the flashpoints around which political struggles over temporal orders and the future take place. This has led to efforts to limit the spaces for engagement by contesting actors through holding negotiations in secret and locking in progressive liberalisation so that the future is protected from distributional struggles.

THE CASE: Recalibrating Time-Future in Education Services, Global Markets and Trade Agreements

Global education services markets, and the inclusion of education in trade deals, are recent developments. A key concern in this paper is the implications of this shift for the temporal rhythm of the academy. Put in terms of a question, how have higher education actors' orientations toward higher education markets, services economies and trade agreements 
been recalibrated and realised, and what does this mean for the temporal reorientation of the university and its actors in the higher education sector?

To help answer this question, I broadly focus on the dominant countries engaged in advancing education trade agendas - Australia, New Zealand, the UK and the USA - who by the 1960s were faced with major political-economic challenges to search for bases for longterm capital accumulation'.

I draw on selected policy documents, statistics and other trade figures (particularly from Australia), where (mostly higher) education now features as a services sector to generate GDP (Robertson and Olds, 2018). As my focus is on the ways in which we understand efforts to shape the future, this case analysis offers an illustrative/exploratory rather than exhaustive account of the different ways we can see these processes at work.

\section{Imagining higher education as a services sector}

Most efforts to chart the process of reimagining public good sectors like education as key services sectors to underpin a new long wave of accumulation, point to the influential effects of the oil shocks in the 1970s and the economic crisis that followed. However, Harvey (2005) shows not only that the United States faced growing competition from Western Europe and Japan by the end of the 1960s, but also that newly industrialising countries in Asia had begun to challenge US hegemony during this period. Bell's (1976) pronouncement that a "post-industrial" society had somehow emerged organically out of an industrial society was symptomatic of periods like this; that is, of attempts to reimagine a new kind of economy and society from a collapsing social order, and the conditions that might bring this about.

If the forecasters were now hard at work, so too were the ideologues over how best to manage the economy. What was clear was that the 1970s economic crisis had created a crisis of rationality over Keynesianism as the post-war model of development. At the same time, an alternative narrative was promoted by "a minority of ultra-liberal economic theologians" (Hobsbawn, 1994: 409) committed to a free market model as the engine for economic development. In Beckert's language, this was an alternative story about the future, put into battle with an existing narrative. For Keynesians, high wages, full employment and the welfare state were represented as creating the consumer demand that fuelled expansion. For neoliberals, their story was that the future wealth of the nation depended on minimising the role and cost of government, creating conditions whereby the private sector would flourish and boost productivity.

In the years that followed, it was the ultra-liberal or neo-liberal neo/liberal imaginary of choice and markets, entrepreneurship, efficiency through competition, opening up public monopolies to private sector actors, and so on which won the day (Berger et al., 1974). This alternative vision of the future set in train a new kind of logic in sectors like education; one that privileged social attributes such as individualism, competitiveness, and forms of calculation aimed at maximising returns on education investments into the future. Most importantly, this neoliberal imaginary, with its cultural and institutional frames, was dependent upon and produced a new cognitive orientation to the future (Sennett, 2006). 
If the governance of education was being refashioned in micro-economic policy through narratives such as human capital, consumerism, and efficiencies, so too was education being increasingly viewed in macro-economic policy as central to the development of a global knowledge and services-based economy (Robertson et al., 2002; Robertson, 2009). Indeed, by the end of the 1970s, trade in services was becoming a major component of international trade and accounted for an increasing proportion of international investment. However, services sectors present trading governments and transnational firms with huge problems because of remaining protections around public services, or because domestic regulations around foreign direct investment inhibit the entry of transnational actors. Governments, allied firms and competitive organisations wanting to enter new markets in other parts of the globe argued that state monopolies on services, from telecommunications to banking, education and health, should be deregulated and opened up to competition, and to being included as a services sector, distinct from the production of goods (Marchak, 1994: 84).

Imagining and materializing education as a globally-traded services sector has taken, and continues to take, a considerable amount of political work, not least because education continues to be regarded in many societies as a public service. One reason for the easier alignment between the university and global services markets is that 'internationalisation' is central to the missions of most universities. Yet, here internationalisation itself has been transformed from being a knowledge claim around a cosmopolitan ideal to being understood as an economic strategy (Marginson and Considine, 2000).

A second reason for the easier alignment is that from the early 1980s onwards, governments in a small number of western economies (especially Australia, New Zealand, and the United Kingdom) took the view that higher education could offer them a comparative advantage in trade terms, and that they should therefore locate international education in their trade briefs and departments. Facing out to the Asian region in particular, 'importing' higher education provided an instant means for boosting income as a result of being able to charge full-fees. For cash-strapped universities having to expand access to a larger number of national students with the same resources, international students became a welcome source of revenues. The result was a spectacular increase in the volume of student movement from the Asian region to destinations like Australia and New Zealand, in turn transforming local infrastructures and cultures (Robertson and Kedzierski, 2016).

Trade in education services now constitutes an important 'industry' in countries like Australia, New Zealand, and the United Kingdom. Competition has led to major innovations in the sector, which now includes specialist firms like recruiters, the growth of for-profit universities which specialize in on-line learning aimed at part-time learners, new financial products aimed at extending student enrolment, new education divisions built into global firms that have realigned their investment strategies in line with projections around 'emerging markets', and so on. Yet with such a significant investment in, and dependence upon, the 'education export market', there is also concern expressed as to how best to maintain or increase market-share, and most importantly, how to ensure that governments don't return to 'national interest' agendas and limit international investment in education.

Australia is a particularly interesting as a country in that it has gone furthest amongst the top services exporting countries in reimagining and strategizing the materialization of 
education as an education services sector. Education is described by the Australian government not only in trade terms as an 'export', but is placed into equivalence with other extractive resources traded on the global market - gold, coal and iron ore, as Figure 1 shows.

\section{$<<I N S E R T$ FIGURE 1 ABOUT HERE $>>$}

Most recently, Australia has developed what it calls a comprehensive international education' strategy that projects well into the future -2025 . This projection this projection is justified by the extrapolation of the past, as Figure 2 shows; a trend in the direction of increasing growth.

$<<$ INSERT FIGURE 2 ABOUT HERE $>>$

\section{<<INSERT FIGURE 3 ABOUT HERE >>}

Its national and institutional level strategies are also shaped by gathering considerable amounts of data - some of which is available to the public, and other that is more granulated, and sold at cost to buyers (see Figures 2 and 3). It engages in considerable amounts of horizon scanning, and produces a range of reports and ways of representing developments in the sector and their relation to the future. All provide a narrative linking the past and present with an assumed future of education as a services sector and part of global trade flows.

In May 2016, the Australian Government launched a National Strategy aimed at expanding the education services sector, composed of "...a trio of key strategies for the expansion of its international education sector: a national strategy for international education, a market development roadmap, and an alumni engagement strategy" (Australian Government, 2016, website) that would make use of innovations such as technology-enabled learning via online or blended delivery programmes. It is instructive to look closely as to how the future is imagined and strategized using techniques and devices such as 'forecasting services' by global accounting firms, 'roadmaps' (with identified competitors), social groups like 'alumni', and other kinds of networks, always in terms of trade and investment.

The National Strategy for International Education 2025 itself, which reflects a "whole-of-sector" approach and sets out a 10-year plan for further developing Australia's position as a global leader in education and training. The national strategy is based around three pillars: "strengthening the fundamentals" (including improvements to student services and quality assurance), "making transformative partnerships" (which focuses on links at home and abroad, alumni networks, and visa policy), and "competing globally."

The Australian International Education 2025 (AIE2025) market development roadmap, is the product of both extensive consultations within the sector and research from Deloitte Access Economics. It provides a 10-year market development framework for Australia's education exports, including "gamechanging" strategies to build scalable, collaborative networks of education 
providers, attract capital to fuel the sector's expansion, and target key markets abroad.

The Australia Global Alumni Engagement Strategy 2016-2020 outlines a five-year plan to strengthen and engage Australia's foreign alumni with the broader goals of enhancing the country's diplomatic access and influence and building trade and investment links.

"This signals the sector's and the government's commitment to work together to advance international education by identifying new products and new opportunities for expansion, and building on our current presence in existing markets," said Minister Colbeck (Australian Government, 2016, website).

The temporal lexicon around the future is distinctive in this strategic policy document: a 'ten year plan', 'game changing strategies', 'expansion', 'future innovations', and so on. The stakes are high for the government and so are the potential risks of losing market share, given that international education is estimated to be worth AUS\$19.6 billion (US\$14.7 billion) a year to the Australian economy; it is the nation's third largest export sector. As competition has stepped up, so too have concerns over who has what share of the global education services market, and how that might play out in the future. Key actors (governments, institutions and transnational firms) within economies that include Australia, New Zealand and the United States, have intensified their interest in the ways in which domestic and international regulatory systems of the inter-state world currently, or might into the future, impede the project of creating an expanding global trading system in services - an issue I now turn to.

\section{Globalising cognitive frames and orientations - but failing}

Transforming higher education from being widely understood as a public good into a global services sector governed through global trade rules requires complex processes of reframing, normalising and socialising via a range of devices, institutional arrangements, and new social relations. To be successful across global space, this process requires the globalising and embedding of new cognitive frames.

Challenging the cognitive and material barriers to global trade in services has been on the agenda since the early 1980s, spearheaded by service coalitions formed to lobby for change, including the US-based Coalition of Service Industries (CSI). The CSI used its lobbying capacity to shape negotiations taking place under the General Agreement on Tariffs and Trade (GATT) during the 1980s, to include services and not just goods in the mandate of the GATT. Organised interests in the United States as well as Australia, New Zealand and the United Kingdom were keen to promote a new post-GATT structure, the World Trade Organization (WTO), with an expanded trade agenda.

In 1995 the WTO was launched to "...formalize, deepen and widen an international system of trade regulation. It was also to bring greater coherence to global policymaking by drawing together the work of the WTO with that of the IMF, the WB as well as to develop relations with other bodies" (Wilkinson, 2002: 129). The WTO now presided over the GATT, along 
with two new areas of trade, the General Agreement on Trade in Service (GATS), and Trade Related Intellectual Property Services (TRIPS).

Members who joined the WTO opted in under a single undertaking to a series of binding rules and a built-in agenda to engage in ongoing negotiations leading to progressive liberalisation into the future. A complex set of technologies and devices to secure this cognitive orientation to the future also determined the work of the actors and their relations to each other, from frameworks of rules laying out obligations governing trade in services, to annexes on specific services sectors, and schedules detailing the liberalisation commitments of each WTO member. An exemption would only be granted under GATS Article 1.3 (c); as "...supplied neither on a commercial basis nor in competition with one or more service suppliers" if the service could show that it existed in a completely decommodified form, untainted by the market.

The GATS mechanisms are worth dwelling on because of their distinctive temporal and cognitive orientation to the future. The first is progressive liberalization. This means that becoming a member of the WTO (there are now 162 countries) means that a country must commit to 'free trade' policies into the future. Second, negotiations around agreed sectors followed a 'positive list' schedule. The member state lists those service sectors and modes that it is prepared to negotiate over and commit whilst the rest are excluded from the agreement. Switzerland, for example, only committed its private universities in its GATS agreement. Third, once the agreement is in place, the rights of the investor take precedence. Any government who decides to limit or curtail investment, or indeed to nationalize a sector (perhaps as a result of a shift in political ideology), will be asked, via a dispute settlement mechanism, to pay the investor future lost income. This asymmetrical relationship between investors in education services and the needs of a community regarding education is an example of what Beckert (2016) refers to as a relationship between instruments and distributional struggles.

Despite efforts to lock in a particular cognitive orientation to the future that reflected the interests of investors in education, the GATS negotiations proved to be hugely controversial and in the end largely failed. Each meeting was marked by protests; the iconic Battle in Seattle in 1999 was hugely resonant. Between meetings, campaigners organised and promoted education as a human right and not a commodity. To do so, they enrolled a competing narrative to promote a different imaginary around the future. Campaigners pointed particularly to the right to education as recognised in international instruments most prominently the International Declaration of Human Rights launched in 1948 after World War II, and the Convention of the Human Rights of the Child launched in 1959. In a specially commissioned report on GATS, the Special Rapporteur for Education stated that the "rapid development of international trade law necessitated a decisive reaffirmation of education as a human right" (Tomasevski, 2001: 5). This led the Rapporteur to observe

...the liberalization of trade in services, without adequate government regulation and proper assessment of its affects, can have undesirable effects. Different service sectors require different policies and time frames for liberalization and some areas are better left under governmental authority (p. 20)...While the WTO Agreements provide a legal framework for the economic aspects of the 
liberalisation of trade, they focus on commercial objectives. The norms and standards of human rights provide the means of providing a legal framework for the social dimensions of human rights...A human rights approach to trade liberalisation emphasizes the role of the State, not only as negotiator of trade rules and setter of trade policy, but also as duty bearer for human rights (Tomasevski, 2001: 10).

In her report, the Commissioner pointed to the different ways in which GATS, were it to be implemented, might exaggerate social inequalities in education if the state was unable to have a degree of flexibility over the organisation of education.

From a commercial perspective, holding countries to their commitments to liberalise is important to ensure transparency and predictability in international trade and the payment of compensation is a legitimate commercial response to the settlement of disputes. From a human rights perspective, however, the focus is less on predictability and more on the need for flexibility to modify or withdraw commitments to liberalise services where experience demonstrates that a commitment constrains or limits the enjoyment of human rights. The need for flexibility is particularly relevant for developing countries given that they are in a dynamic process of building infrastructures. ...Moreover, while compensation to affected parties might be appropriate in some cases upon withdrawal of commitments, a human rights approach would question whether states should be sanctioned for taking action to protect human rights (2001: 28).

These very publicly aired concerns, along with growing disquiet amongst many developing countries as to what free trade really meant for their economic development more generally, resulted in the WTO GATS negotiations stalling by 2005 . The inability to convince other actors in the economy to share in similar expectations about education as an investment sector means this future is not likely to be realised (Beckert, 2016: 275). As a result, the strategy failed to also shape actors' cognitive orientation toward education's future as a services sector subject to WTO rules.

\section{The 2008 global financial crisis - a new narrative and strategy}

Crises generate new semiotic and material opportunities, opening the space for new accounts of what is to be done to shape and secure the future. By 2011, a new wave of mega-trade in services negotiations had begun in earnest, stimulated by the global financial crisis in 2008, the decline in productivity in Europe and the United States, and growing unemployment (Robertson and Komljenovic, 2017). Education as a 'services sector' was again on these agendas, though those contesting its inclusion continued to point to its public good and not private or trade status (Gould, 2014).

These negotiations included the Trans-Pacific Partnership (TPP) involving 12 countries in the Pacific Region dominated by the United States; the Comprehensive Economic Trade Agreement (CETA) between Canada and Europe; the Transatlantic Trade and Investment 
Partnership (TTIP) involving Europe and the United States; and the Trade in Services Agreement (TISA) largely between OECD countries. However, this time all negotiations have been held in secret, and all involve frameworks and instruments that aim to lock in the interests of investors into the future.

This more coercive, secretive approach to realigning interests is a fraught one, as the lack of shared expectation about the future of education as a services sector places limits on its potential to get traction on, and control, the future. The formal withdrawal of the United States from the TTP (and likely TTIP) following the election of Donald Trump to the US Presidency in late 2016 is a case in point. Trump's appeal to US voters is that he argued they did not share in the view that global trade deals were good for American workers and their jobs.

Nevertheless, these mega-trade deals are negotiations that have been completed (with CETA, TPP awaiting final approval by the various members) or are continuing (TISA, TTIP). This raises the question as to how the future for education is imagined, and what kinds of discourses, devices, institutional arrangements and social norms are being deployed to do the work of creating shared expectations about that future and the temporal order of capitalism.

One such device is the 'Impact Assessment' used to convince sceptics and enrol promoters, and thus align expectations, as to the longer-term outcomes of these deals. The Impact Assessment for TTIP was conducted by the Centre for European Policy Studies (CEPS), a probusiness think-tank located in Brussels (see Pelkmans et al., 2014). This Impact Assessment was used by the European Commission to project the annual gains to be had from the TTIP of $€ 119 \mathrm{~b}$ for the EU and €95b for the USA, suggesting that European countries would be the main beneficiaries.

This particular approach to Impact Assessments makes specific assumptions about capitalist markets and futures. De Ville and Siles-Brügge (2015) show that the TTIP Impact Assessment depends on Computational General Equilibrium Modelling (CGEM). CGEM embraces neoclassical economic assumptions: there is no excess demand, all markets clear under conditions of perfect competition, and we can model market processes through numerical data and results. Yet De Ville and Siles-Brügge (2015) argue CGE models have been subject to critique, even within economics, in that there are information asymmetries, individuals are often driven by more complex sets of values, and labour and product markets rarely clear at the same time. The CGEM is used to model three kinds of policy options; from a baseline option to a comprehensive and ambitious one, of removing all duties, reducing tariff and non-tariff barriers (NTBs) on goods and services, and on government procurement. For the base-line option, the gains are negligible. The gains on the more comprehensive scenario, the one used by the Commission to make the economic case for TTIP, are presented as more substantial. And it is this latter future that is used by the Commission in its public defence of TTIP.

De Ville and Siles-Brùgge (2015) argue that this kind of Impact Assessment acts like a black box; it not only skews the terms of the economic and political debate in directions that suit 
the Commission's agenda, but also has a particular narrative that it offers of the future. This future does not include the costs that result from macro-economic adjustments - such as alignment to new standards, the displacement and retraining of workers, potential welfare losses in the society, or the threat to public policy goals (De Ville and Siles-Brùgge, 2015: 669). In contesting this Impact Assessment narrative, De Ville and Siles-Brùgge (2015) present the case of the North American Free Trade Agreement, which also used the CGEM. They compare the ex-post evidence with the ex-ante claims which show that both Mexico and Canada fared significantly worse than predicted in terms of economic gains (especially around costs over labour displacements). In relation to TTIP, they argue a combination of the assumptions built into the CGEM, the regulatory mechanism to be used, and the capacity to liberalise across the board, exaggerate the potential economic benefits of TTIP whilst under-playing other likely outcomes - such as a race-to-the-bottom in social, educational and environmental standards.

A second temporal device in these trade deals is 'the ratchet effect'. Any new activity in the sector into the future will be subject to the principles of the market and the interests of the investors, as enshrined in the trade agreement. The ratchet process aims to draw more and more of the society into functioning like a capitalist market. Linked to this is a third device that now works the opposite way to the GATS; it deploys a negative and not a positive list. A negative list means identifying all those activities that are to be excluded so that what is not on the list is included. The expectation is that the negotiators have a god-optic on the present and the future; as an all seeing and knowing eye that can see sufficiently to know what to anticipate. Through these two devices, we see education traders and investors colonising the future of higher education, sanctioned the governments' negotiators, so that the future is not locked in as a resource for global capitalism.

\section{Concluding Thoughts: Higher Education and Temporal Order of Capitalism}

I began this paper by arguing that higher education, as a knowledge-producing sector, has its own temporal rhythms and ordering processes. One temporal modality is toward the past, as accumulated knowledges become resources for the present, and as academics carry out their work as curators and custodians. A second temporal modality is toward the present via the unfolding of a day, term and year, and the patterns of teaching, learning, marking, researching, administering, that punctuate, thus creating the rhythm of an academic year in particular way. A third modality is the future - one marked by the uncertainty of the research process, the serendipity of the unexpected, and the happy coincidences that turn into something - perhaps a Nobel Award.

There is little doubt the academy is being challenged not only to be efficient in our use of time and more certain in what we do. These developments are about controlling the present and the future. Yet to a large extent, they are also the outcomes of the leakage of the dynamics of capitalism into the academy, as higher education is increasingly drawn into becoming a value-producing sector in its own right. 
Yet it is through looking more closely at the ways in which higher education futures are regarded as resources to be reimagined, colonised and exploited for the purposes of investor certainty, that we see the full import of a different temporal imagination and rhythm on the sector. These trade agreements aim to not only transform the future into an extended present (Nowotny, 1994), but the extended present contains the progressive cognitive reorientation of actors to a future shaped by capitalist dynamics (Beckert, 2016). This case helps to generate new insights around time future in a substantive sense, and might become the basis for further theoretical work of the kind that Nowotny and others have called for.

And if time is political and higher education is also in a normative sense one of the spaces that we might use to think critically about the future, then our social theories can be put to work to change the current state of affairs. In this regard, I have shown that ongoing efforts to commodify higher education, on the one hand, and to colonise higher education futures exclusively to serve the interests of economic investors, on the other, continue to be contested. Destabilising these possible futures are the huge contradictions that now emerge, particularly for higher education institutions, and the risks to knowledge production more generally as higher education gets more tightly wound into the circuit of capital, its temporalities, the dynamics of capitalism, and tendencies toward crisis.

However, this new temporal order is yet to become common sense, and the existing order is yet to die. Competing narratives about the future of higher education and higher education's futuring thus open the space for recognising the importance of contesting these narratives and the devices and other mechanisms aimed at socialising and normalising one narrative over another. And if the future is a resource to be claimed, then maybe we might also begin the process of imagining a future to be realised through an alignment of expectations that places knowledge, openness, sharing and community as an alternative cognitive orientation toward the future.

\section{References}

Adam, B. (1990) Time and Social Theory, Polity Press: Cambridge.

Adam, B., (1995) Timewatch: The Social Analysis of Time, Polity Press: Cambridge.

Australian Government (2016) National Strategy for International Education 2025, Australian Government, Canberra.

Back, L., (2016) Academic Diary, London: Goldsmiths Press.

Beckert, J. (1996) What is sociological about economic sociology? Uncertainty and the embeddedness of the economic action, Theory and Society, 25, pp. 803-40.

Beckert, J. (2014) Capitalist Dynamics, Fictional Expectations and the Openness of the Future, MPIfG Discussion Paper, 14/7. 
Beckert, J., (2016) Imagined Futures: Fictional Expectations and Capitalist Dynamics, Cambridge: Harvard University Press.

Berger, P. Berger, B. and Kellner, H., (1974) The Homeless Mind, New York: Vintage Books.

Blass, E., Jasman, A., and Shelley, S., (2010) Visioning 2035: the future of higher education sector in the UK, Futures, 42, pp. 445-53.

De Ville, F., and Silles-Brügge, G., (2015) The Transatlantic Trade and Investment Partnership and the Role of Computable General Equilibruim Modelling: An Exercise in Managing Fictional Expectations, New Political Economy, 20 (5), pp. 653-78.

Hägerstrand, T., (1985). Time-geography: Focus on the Corporeality of Man, Society, and Environment. In: The Science and Praxis of Complexity. Tokyo: The United Nations University. pp. 193-216.

Harvey, D. (2005). A Brief History of Neoliberalism, Oxford University Press: Oxford. Hobsbawm, E. (1999) The New Century, London: Abacus.

Hope, W., (2010) Crisis of temporalities: global capitalism after the 2007-08 financial collapse, Time and Society, 20 (1), pp. 94-118.

Komljenovic, J. and Robertson, S., (2016) The dynamics of market- making, J. of Education Policy, 31:5, 622-636

Lapping, C., (2016) The explosion of real time and the structural conditions of temporality in a society of control, Discourse: Studies in the Cultural Politics of Education, DOI: 10.1080/01596306.2016.1185092

Marchak, P. (1991) The Integrated Circus: The New Right and the Restructuring of Global Markets, Montreal: McGill University Press.

Marginson, S. and Considine, M. (2000) The Enterprise University: Power, Governance and Reinvention, Cambridge: Cambridge University Press.

Noonan, J., (2016) Thought-time, money time and the conditions for free academic labour, Time and Society, 25 (2), pp. 213-33.

Nowotny, H., (1992) Time and social theory: toward a social theory of time, Time and Society, 1 (3), pp. 21-454.

Nowotny, H., (1994) Time: the Modern and Postmodern Experience, Cambridge: Polity

Nowotny, H., (2016) The Cunning of Uncertainty, Cambridge: Polity

Pelkmans, J., Lejour, A., Schrefler, L., Mustilli, F., and Timini, J., (2014) The Impact of TTIP:

The Underlying Economic Model and Comparisons, No. 93, October 2014. Brussels: Centre for European Policy Studies.

Rizvi, S., Donnelly, K., and Barber, M. (2013) An Avalanche is Coming: The Future of Higher Education, IPPR: London 
Robertson, S. and Muellerleile, C. (2016) Universities, the Risk Industry and Capitalism: A Political Economy Critique. In Romuald Normand and Jean Louis Derouet (Ed.), A European politics of Education? Perspectives from Sociology, Policy Studies and Politics, London and New Your: Routledge.

Robertson S. L. and Kedzierski M. (2016) On the Move, Globalising Higher Education in Europe and Beyond, Special Issue - D. Black (Editor) of Language Learning Journal, 44 (3).

Robertson, S and J Komljenovic, J. (2017) Forum Shifting and Shape Making in Europe's Negotiations on Trade in (Higher Education) Services. In R. Barnett, M. Peters and R. Heraud (eds) The Global University, Frankfurt: Peter Lang.

Robertson, S., and Olds, K. (2018), Higher education in a global world, in T. Strike (ed., ) Higher Education Strategy and Planning A Professional Guide, London and New York: Routledge.

Robertson, S. Bonal, X and Dale, R. (2002) GATS and the Education Service Industry, 46 (4), pp. 472-96.

Sennett, R. (2006) The Culture of the New Capitalism, New Haven and London: Yale University.

Smith, S., (2015) Multiple temporalities of knowing in academic research, Social Science Information, 54 (2), pp. 149-176.

Tomasevski, K., (2001) Annual Report of the Special Rapporteur on the Right to Education, submitted to the Commission on Human Rights, Economic and Social Council, New York.

Vincent Lancrin, S., (2004) Building futures scenarios for universities and higher education: an international approach, Policy Futures in Higher Education, 2 (2), pp. 245-60,

Vostal, F., (2015) Academic life in the fast lane: the experience of time and speed in British academia, Time and Society, 24 (1), pp. 71-95.

Vostal. F., (2016) Accelerating Academia: The Changing Structure of Academic Time, London: Palgrave Macmillan.

Wilkinson, R. (2002) Global Monitor: The World Trade Organisation, New Political Economy, 7 (1): 129-141.

Winham, G., (2005) The evolution of the global trading regime, in J. Ravenhill (ed.). Global Political Economy, Oxford: Oxford University Press.

Ylijoki, O.-H. \& Mäntylä, H. (2003) Conflicting time perspectives in academic work. Time and Society, 12(1), 55-78. 


\section{Insert FIGURES}

Australia's top 25 exports, goods and services, 2012

\begin{tabular}{|c|c|c|c|c|c|c|}
\hline Rank & Commodity & 2010 & 2011 & 2012 & $\begin{array}{l}\text { \% growth } \\
2011 \text { to } 2012\end{array}$ & 5 year trend growth \\
\hline 1 & Iron ores \& concentrates & 49,380 & 64,097 & 54,689 & -14.7 & 28.7 \\
\hline 2 & Coal & 42,967 & 46,691 & 41,273 & -11.6 & 10.6 \\
\hline 3 & Gold & 14,438 & 15,077 & 15,525 & 3.0 & 4.9 \\
\hline 4 & Education-related travel services & 16,597 & 15,155 & 14,487 & -4.4 & 2.7 \\
\hline 5 & Natural gas & 9,425 & 11,084 & 13,418 & 21.1 & 17.4 \\
\hline
\end{tabular}

Figure 1: Education represented as equivalent to extractive industries that are traded.

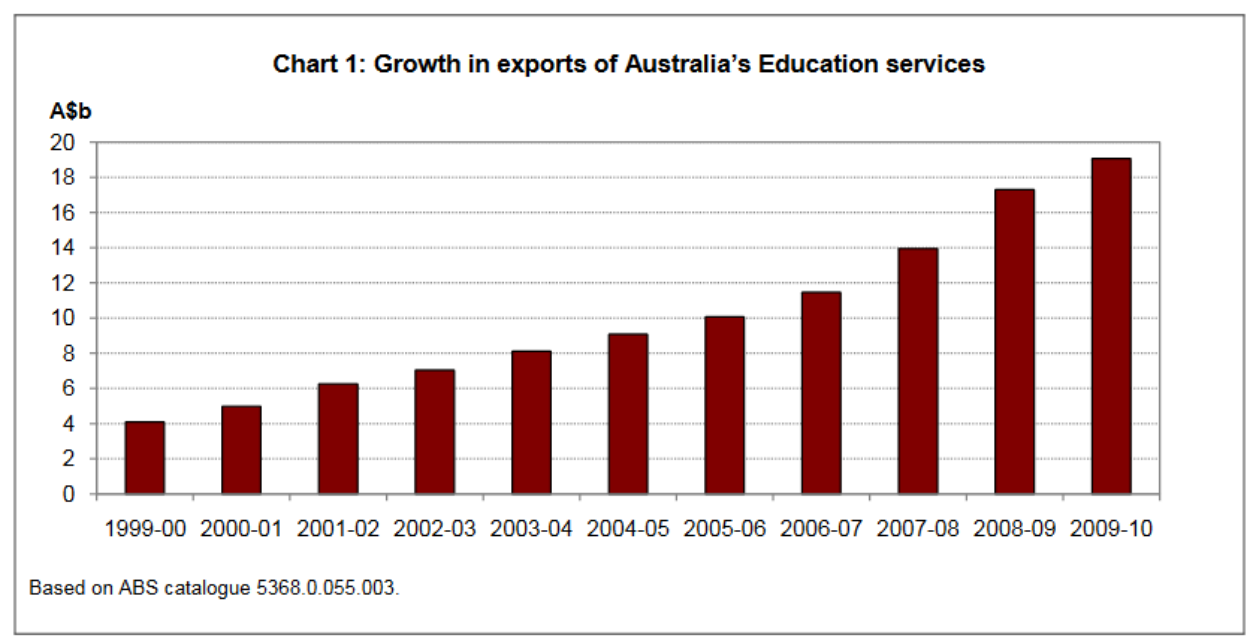

Figure 2: Assumptions of the future through representing the past. 


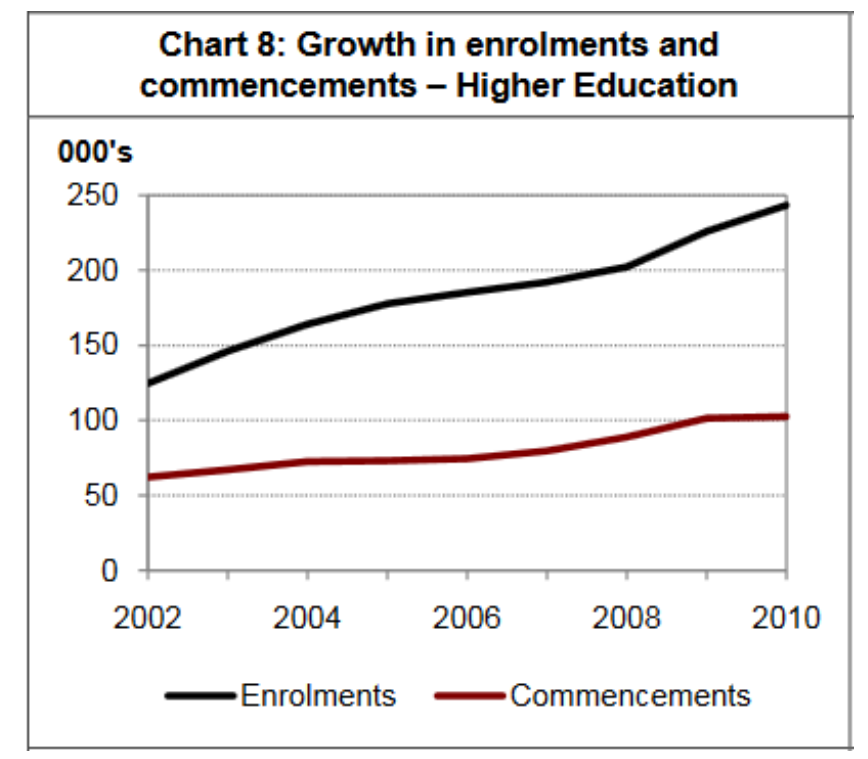

Figure 3: The circumstances and decisions of education consumers 